\title{
Antidepressant activity of Kampavatari rasa, an Herbo-mineral preparation in swiss albino mice
}

\author{
Rashmi B.R ${ }^{1^{*}}$, Ebrahim N.K.C ${ }^{2}$ \\ ${ }^{1}$ Lecturer, ${ }^{\mathbf{2}}$ Senior Lecturer, ${ }^{\mathbf{1}, \mathbf{2}}$ Dept. of Physiology, ${ }^{\mathbf{1}}$ A.J Institute of Allied Health Sciences, Kuntikan, Mangalore, Karnataka, India, \\ ${ }^{2}$ Faculty of Medicine, Quest international university, Perak, Malaysia
}

\begin{abstract}
Objective: Depression is a characterized by low mood and lack of activity that can implicit on person's thoughts, behavior, feelings, and sense of well-being.

Materials and Methods: Equal number $(\mathrm{n}=6)$ Swiss albino mice weighing 20-25gm were randomly divided into 4 groups having 6 animals in each group as Control (1\% Gum acacia), Standard (Imipramine-10mg/kg), Kampavatari Ras-Plain (KVR-P) (200 mg/kg) and Kampavatari Ras-Gold (KVR-G) (200 mg/kg). Each mouse was administered with respective vehicle / drug one hour prior to experiment. First two minute reading was not recorded but last four minutes activity was noted for mobility and immobility both in forced swim and tail suspension test.

Statistical Analysis: Observations are mean \pm S.E.M. One- way ANOVA test followed by Post-hoc Dunett's Multiple comparison. p<0.05 was considered statistically significant.

Results: Mean duration of immobility for the control group was observed to be $141.33 \pm 5.5$ sec and $164.16 \pm 10.54$ sec respectively for forced swim test (FST) and tail suspension test (TST). The standard (Imipramine, $10 \mathrm{mg} / \mathrm{kg}$ ) showed was $211.83 \pm 48 \mathrm{sec}$ and $212.5 \pm 6.80$ respectively for forced swim test (FST) and tail suspension test (TST). Kampavatari Ras-Plain (KVR-P) at the dose of $200 \mathrm{mg} / \mathrm{kg}$ showed immobility time of $189 \pm 48 \mathrm{sec}$ and $203.55 \pm 6.02$ for forced swim test (FST) and tail suspension test (TST) respectively. Similarly, Kampavatari Ras-Gold (KVR-G) at the dose of $200 \mathrm{mg} / \mathrm{kg}$ showed immobility time of $210 \pm 9.8 \mathrm{sec}$ and $193.33 \pm 6.7 \mathrm{sec}$ for forced swim test (FST) and tail suspension test respectively.

Conclusion: Kampavatari Ras-Plain and Kampavatari Ras-Gold at the dose of 200mg/kg has shown antidepressant effect when compared to control which is comparable to standard Imipramine in Swiss albino mice.
\end{abstract}

Keywords: Anti-depressant effect, Forced swim test (FST), Tail suspension test (TST), Kampavatari Ras-Plain, Kampavatari Ras-Gold.

\section{Introduction}

A disturbance in regulation of mood and behavior is termed as depressive disorders with other subdivision as bipolar disorder etc The basic symptoms of depression are mood depression, loss of concentration and interest, self-low esteem, insomnia, weight loss and appetite changes with recurrent suicidal tendency. ${ }^{1}$

Decrease in the level of noradrenaline and or serotonin at the respective synaptic cleft of CNS is attributed to development of depression as per classical theory, along with role of oxidative stress in the causation of the same as per recent theory. ${ }^{2,3}$

A concept of neuro-degeneration and reduced neurogenesis in the Hippocampus has also been proposed very recently in the causation of depression. ${ }^{4,5}$

In spite of development of new molecules and targets, many patients with mood disorders especially with depression go undiagnosed and untreated. The current therapy affords come improvements in symptoms, but nevertheless, they are not devoid of side or adverse effects and the tricyclic antidepressants being efficacious, takes minimum two weeks to show its visible therapeutic effects which poses a drawbacks in treating depression. ${ }^{6}$

Kampavatari Rasa (KVR) is a unique Ayurvedic herbomineral formulation mentioned in the classics Rasa Raj
Sundar in Vata vyadhi and indicated mainly in Kampavata which resembles Parkinson's disease.

Kampavatari rasa is classically prepared by triturating Tamra bhasma (Copper ash) and Rasa Sindura (Mercurial preparation) in equal quantity with Katuki swaras (Picrohiza kurroa) for 21 times. $^{7}$ But, for this study, we will purchase the medicine from an registered ayurvedic shop and perform the experiment.

\section{Materials and Methods}

This study was approved by Institutional Animal Ethics Committee Yenepoya Medical College, Derlakatte, Mangalore, Karnataka. Gum acasia and Imipramine was obtained from Department of Pharmacology, Yenepoya Medical College, Derlakatte, Mangalore, Karnataka, India. Kampavatari ras plain and gold was purchased for Laxmi Ayurvedic Dispensary, Central Market, Mangalore, Karnataka, India.

\section{Procedure}

Equal number $(\mathrm{n}=6)$ Swiss albino mice weighing 20-25gm were randomly divided into 4 groups having 6 animals in each group as Control (1\% Gum acacia), Standard (Imipramine-10mg/kg), Kampavatari Ras-Plain (KVR-P) (200 mg/kg) and Kampavatari Ras-Gold (KVR-G) (200

*Corresponding Author: Rashmi B.R, Dept. of Physiology, A.J Institute of Allied Health Sciences, Kuntikan, Mangalore, Karnataka, India Email: rashmichandrashekar@gmail.com http://doi.org/10.18231/j.ijcaap.2019.017 
$\mathrm{mg} / \mathrm{kg}$ ). Each mouse was administered with respective vehicle / drug one hour prior to experiment. First two minute reading was not recorded but last four minutes activity was noted for mobility and immobility both in forced swim and tail suspension test.

\section{Forced swim test (FST)}

In forced swim test, mice are considered immobile when floating motionless or making only those movements necessary to keep its head above the water surface. Duration of immobility is recorded during the last 4 minutes in the 6 minutes test ${ }^{[8]}$.

\section{Tail suspension test (TST)}

In tail suspension test, mice are considered immobile only when they hang passively and completely motionless for at least one minute in an 8 minute test and duration of immobility is calculated ${ }^{[9]}$.

\section{Statistical Analysis}

ANOVA followed by Dunnett's Multiple Comparison test was used for the analysis. ${ }^{*} \mathrm{P}<0.05$ was considered statistically significant.

\section{Results}

Table 1: Anti-depressant effect of Kampavatari Ras-Plain and Kampavatari Ras-Gold in Swiss albino mice

\begin{tabular}{|c|c|c|c|c|}
\hline Groups & Drugs & Dose & FST & TST \\
\hline I & $\begin{array}{c}\text { Control (1\% } \\
\text { Gum acacia) }\end{array}$ & $3 \mathrm{ml} / \mathrm{kg}$ & $141.33 \pm 5.5 *$ & $164.16 \pm 10.54 *$ \\
\hline II & $\begin{array}{c}\text { Standard } \\
\text { (Imipramine) }\end{array}$ & $10 \mathrm{mg} / \mathrm{kg}$ & $\begin{array}{c}211.83 \pm 48 * \\
* *\end{array}$ & $212.5 \pm 6.80 * * *$ \\
\hline III & KVR-P & $200 \mathrm{mg} / \mathrm{kg}$ & $189 \pm 48 * * *$ & $\begin{array}{c}203.55 \pm 6.02 * * \\
*\end{array}$ \\
\hline IV & KVR-G & $200 \mathrm{mg} / \mathrm{kg}$ & $210 \pm 9.8 * * *$ & $193.33 \pm 6.7 * * *$ \\
\hline
\end{tabular}

$\mathrm{n}=6$, Observations are mean \pm S.E.M. One- way ANOVA test followed by Post-hoc Dunett's Multiple comparison FST-Forced Swim Test, TST-Tail Suspension Test, KVR-PKampavatari Ras-Plain, KVR-R-Kampavatari Ras-Gold ${ }^{*} \mathrm{p}>0.05$ - Not significant, ${ }^{* *} \mathrm{p}<0.05$ - Significant.

\section{Discussion}

The present study tried to evaluate antidepressant of two herbo-mineral preparation named Kampavatari Ras-Plain and Kampavatari Ras-Gold, both at the dose of $200 \mathrm{mg} / \mathrm{kg}$ in comparison with control and the standard drug Imipramine.

In this study we used Forced swim test and Tail suspension test to elicit depression. The immobility displayed by animal when subjected to unavoidable stress is thought to reflect a state of despair or lowered mood, which are thought to reflect depressive disorders in humans. Similar is the case, when the animals are suspended with its tail with head upside down.
In our study, the mean duration of immobility for the control group was observed to be $141.33 \pm 5.5 \mathrm{sec}$ and $164.16 \pm 10.54 \mathrm{sec}$ respectively for forced swim test (FST) and tail suspension test (TST). The standard (Imipramine, $10 \mathrm{mg} / \mathrm{kg}$ ) showed immobility duration of $211.83 \pm 48 \mathrm{sec}$ and $212.5 \pm 6.80$ respectively for forced swim test (FST) and tail suspension test (TST) respectively. Kampavatari Ras-Plain (KVR-P) at the dose of $200 \mathrm{mg} / \mathrm{kg}$ showed immobility time of $189 \pm 48 \mathrm{sec}$ and $203.55 \pm 6.02$ significantly $(\mathrm{p}<0.001)$ for forced swim test (FST) and tail suspension test (TST) respectively. Similarly, even, Kampavatari Ras-Gold (KVR$\mathrm{G})$ at the dose of $200 \mathrm{mg} / \mathrm{kg}$ showed immobility time of $210 \pm 9.8 \mathrm{sec}$ and $193.33 \pm 6.7 \mathrm{sec}$ significantly $(\mathrm{p}<0.001)$ or forced swim test (FST) and tail suspension test respectively (Table 1). However further studies are needed to evaluate the same with more sample size and in different models.

\section{Source of Funding}

None.

\section{Conflict of Interest}

None.

\section{References}

1. American Psychiatric Association. Diagnostic and Statistical Manual of Mental Disorders. Washington, DC: APA Press; 2000.

2. Sarandol A, Sarandol E, Eker SS, Erdinc S, Vatansever E, Kirli S et al. Human Psychopharmacol: Clin Exp 2007; 22(2) 67-73.

3. Ibrahim E, Mustafa N, Arif D. Neurochem Res 2007;32(3)497505 .

4. Baldessarini RJ. Fifty years of biomedical psychiatry and psychopharmacology in America. In: American psychiatry after World War II: (1944-1994). Menninger R, Nemiah, J, eds. Washington DC: American Psychiatric Press; 2000:371412.

5. Musselman DL, DeBattista C, Nathan KI. Biology of mood disorders. In: The American psychiatric press textbook of psychopharmacology. Schatzberg AF., Nemeroff CB, eds. Washington DC: American Psychiatric Press: 1998:549-88

6. Tripathi KD. Essentials of medical Pharmacology. 6th ed. Medical Publishers (P) Ltd: New Delhi, India; 2008.

7. Rohan, P, Prakash, Yaranal, Pallavi, pharmaceutical analytical study of R kampavatari rasa - an ayurvedic herbo mineral formulation. Int J Ayurveda Pharma Res 2016;4(4):8-17.

8. Porsolt R.D, Bertin A, Jalfre M. Arch. Int Pharmacodyn Ther 1997;229:327-36.

9. Steru L, Chermat R, Thierry B, Simon P. The tail suspension test: a new method for screening antidepressants in mice. Psychopharmacol (Berl). 1985;85(3):367- 70.

How to cite this article: Rashmi BR, Ebrahim NKC.
Antidepressant activity of Kampavatari rasa, an Herbo-
mineral preparation in swiss albino mice. Int J
Comprehensive Adv Pharmacol 2019;4(3):82-3.

